ТЕОРЕТИКО-МЕТОДИЧНІ АСПЕКТИ ФОРМУВАННЯ НАУКОВО-ДОСЛІДНИЦЬКОЇ КОМПЕТЕНТНОСТІ ФАХІВЦІВ 3 ІНФОРМАЦІЙНОÏ, БІБЛІОТЕЧНОÏ ТА АРХІВНОÏ СПРАВИ

\title{
THEORETICAL AND METHODOLOGICAL ASPECTS OF FORMATION OF RESEARCH COMPETENCE OF INFORMATION, LIBRARY AND ARCHIVAL SPECIALISTS
}

\begin{abstract}
Статтю присвячено аналізу теоретикометодичних аспектів формування науководослідницької компетентності фахівців з інформаційної, бібліотечної та архівної справи. Згідно з державним стандартом підготовки фрахівців спеціальності 029 «Інформаційна, бібліотечна та архівна справа», метою навчання $є$ підготовка фохівиів, здатних розв'язувати складні спеціалізовані завдання та практичні проблеми в галузі інорормаційної, бібліотечної та архівної справи або в процесі навчання. Під час дослідження було встановлено, що ключовими загальними та фраховими компетентностями орахівців є навички використовувати інфоормаційні та комунікативні технології, здатність до пошуку, опрацювання та аналізу інформації з різних джерел, здатність здійснювати відбір, аналіз, оцінку, систематизацію, моніторинг, організацію, зберігання, поширення та надання в користування інформації та знань у будь-яких форматах. Науково-дослідницьку компетентність розуміємо як системоутворюючий компонент у структурі профресійно компетентності фрахівця з інформаційної, бібліотечної та архівної справи, що є здатністю, необхідною для здійснення пошуку інформації в різних джерелах для розв'язання профресійних завдань, узагальнення, аналізу і синтезу інформації в діяльності, пов'язаній з ї пошуком, накопиченням, зберіганням та використанням.
\end{abstract}

Представлено модель дослідницької діяльності, що передбачає проєктувальний етап (розробка питань методології, методики техніки дослідження), інфрормаційний етап (використовує методи і техніки для отри мання масиву достовірних $і$ репрезентативних даних), аналітичний етап (аналіз, узагальнення, теоретизування даних, опис та пояснення фрактів, обгрунтовування тенденцій і закономірностей), завершальний етап дослідження (розробка практич них рекомендацій і технологій). Формування науково-дослідницької компетентності фрахівців з інформаційної, бібліотечної та архівної справи відбуватиметься ефективніше в прочесі вивчення дисципліни «Основи наукових досліджень». Варто акцентувати на проблемних ситуаціях і практичних завданнях дослідницько-пошукового характеру, мотивуючи студентів до здійснення науково-дослідницької діяльності.
Ключові слова: науково-дослідницька компетентність, фрахівці з інфрормаційної, бібліотечної та архівної справи, дослідницька діяльність, формування.

The article is devoted to the analysis of theoretical and methodological aspects of the formation of research competence of specialists in information, library and archival affairs. There is a purpose according to the state standard of specialists training in the specialty 029 "Information, library and archival affairs". This purpose of training is to train specialists capable of solving complex specialized tasks and practical problems in the field of information, library and archival affairs or in the learning process. It is established that the key general and professional competencies of specialists are the skills to use information and communication technologies; ability to search, process and analyze information from various sources; ability to select, analyze, evaluate, systematize, monitor, organize, store, disseminate and make available information and knowledge in any format. Research competence is understood as a system-forming component in the structure of professional competence of a specialist in information, library and archival affairs. This ability is necessary to search for information in various sources to solve professional problems; generalization, analysis and synthesis of information in activities related to its search, accumulation, storage and use.

The model of research activity is presented, which provides for the design stage of the research (development of research methodology, methods and techniques); information stage (usage of methods and techniques to obtain an array of reliable and representative data) analytical stage (analysis, generalization, data theorizing, description and explanation of facts, substantiation of trends and patterns); final stage (development of practical recommendations and technologies). Formation of research competence of specialists in information, library and archival affairs will take place more effectively in the study of the discipline "Fundamentals of Scientific Research". Particular emphasis should be placed on problematic situations and practical tasks of research and exploration, motivating students to carry out research activities.

Key words: research competence, specialists in information, library and archival affairs, research activities, formation.
Постановка проблеми в загальному вигляді. Погіршення соціально-економічних і політичних умов на сучасному етапі розвитку суспільства призвело до прогресивних інновацій у профресійній освіті. В умовах глобалізації, інформатизації, технологізації освіти підвищились вимоги до професійного навчання майбутніх фрахівців з інфрорма- ційної, бібліотечної та архівної справи. Сучасний ринок соціокультурних послуг потребує фрахівців нового покоління, які мають бути компетентними в соціокультурній сорері, здатними працювати в умовах оновленого інформаційного суспільства, швидко адаптуючись до появи новітніх інфрормаційних технологій. Особливим напрямом удоскона- 
лення профресійної компетентності фрахівця $€$ його активна участь у науково-дослідній діяльності, що підвищує рівень розвитку науково-дослідницької компетентності.

Відповідно до державного стандарту підготовки фрахівців спеціальності 029 «Інформаційна, бібліотечна та архівна справа» [10], метою навчання $€$ підготовка фрахівців, здатних розв'язувати складні спеціалізовані завдання та практичні проблеми в галузі інфрормаційної, бібліотечної та архівної справи або в процесі навчання, що характеризуються комплексністю та невизначеністю умов та передбачають застосування положень і методів інформаційної, бібліотечної та архівної справи.

Серед переліку загальних і фрахових компетентностей $€$ навички використання інфрормаційних і комунікативних технологій, здатність до пошуку, опрацювання та аналізу інорормації з різних джерел, здатність здійснювати відбір, аналіз, оцінку, систематизацію, моніторинг, організацію, зберігання, поширення та надання в користування інформації та знань у будь-яких фрорматах. Крім того, для майбутніх фрахівців інформаційної, бібліотечної та архівної справи актуальними є такі якості, як креативність, готовність до самоосвіти, здатність здійснювати пошукову діяльність, отримувати нові знання, уміння і навички. Особливу роль у процесі фрахової підготовки майбутніх фрахівців з інфрормаційної, бібліотечної та архівної справи відіграє науково-дослідницька діяльність, яка забезпечує підготовку високопрофесійної творчої особистості, здатної до ефективної профресійної діяльності.

Аналіз останніх досліджень і публікацій. Особливості фрормування професійної компетентності майбутніх фрахівців різного профрілю досліджували О. Гура, М. Євтух, І. Зязюн, Н. Микитенко, Н. Ничкало, В. Петрук та інші. Психолого-педагогічні аспекти науково-дослідницької діяльності здобувачів вищої освіти представлено в роботах С. Архангельського, В. Андрєєва, Ю. Бабанського, В. Давидова, В. Крутецького та інших.

Виділення не вирішених раніше частин загальної проблеми. Незважаючи на значний інтерес науковців до пошуку шляхів фрормування науково-дослідницької компетентності майбутніх фрахівців різного профрілю, проблема фрормування означеної компетентності у фахівців з інформаційної, бібліотечної та архівної справи виявляється малорозробленою.

Мета статті полягає у визначенні науково обґрунтованих підходів до визначення змісту й виборі ефрективних методів фрормування науководослідницької компетентності фрахівців з інфрормаційної, бібліотечної та архівної справи.

Виклад основного матеріалу. Вважаємо, що науково-дослідна компетентність співвідноситься зі сорерою науково-дослідної діяльності здобу- вачів вищої освіти. Саме тому сучасна система вищої освіти має бути спрямована на формування професіонала-дослідника, здатного легко адаптуватися до швидко мінливих умов, розв'язувати проблеми завдяки володінню дослідницькими вміннями та сорормованій науково-дослідницькій компетентності.

щодо сутності терміна «науково-дослідницька компетентність», то нині науковці по-різному іії трактують. Представимо найпоширеніші наукові підходи до визначення поняття «науково-дослідницька компетентність», акцентуючи на тому, що деякі вчені замінюють його терміном «дослідницька компетентність» (табл. 1).

Вважаємо, що науково-дослідницька компетентність $€$ системоутворюючим компонентом у структурі профресійної компетентності фрахівця 3 інорормаційної, бібліотечної та архівної справи і являє собою здатність, необхідну для якісної реалізації фрункцій професійної діяльності, зокрема здійснення пошуку інфрормації в різних джерелах для розв'язання професійних завдань, узагальнення, аналізу і синтезу інформації в діяльності, пов'язаній з її пошуком, накопиченням, зберіганням та використанням.

На думку І. Бец, основу науково-дослідницької компетентності становлять уміння виявляти проблему, фрормулювати гіпотезу, підбирати відповідні методи ведення дослідження та обробки отриманих результатів [3]. Підтримуємо вітчизняних науковців у тому, що саме науково-дослідницька компетентність спрямована на фрормування та актуалізацію розумових процесів, інтелектуальних умінь, пізнавальних процедур, розвиток творчого потенціалу особистості, розробку й застосування інноваційних технологій і стратегій. Означена компетентність сприяє самовизначенню, самопізнанню, самовихованню та самореалізації особистості [6].

У контексті нашого дослідження цікавою $€$ модель дослідницької діяльності Ю. Сурміна, розроблена на основі системного підходу, що передбачає чотири етапи:

1) проєктувальний (програмувальний) етап передбачає розробку питань методології, методики і техніки дослідження (результатом є програма дослідження);

2) інформаційний етап зосереджений на використанні методів і техніки для отримання масиву достовірних і репрезентативних даних (результатом є емпіричні дані);

3) аналітичний етап акцентує на аналізі даних, їх узагальненні, теоретизуванні, описі та поясненні фрактів, обґрунтовуванні тенденцій і закономірностей, встановленні кореляційних і причинно-наслідкових зв'язків (результатом є опис і пояснення досліджуваного явища, об'єкта, процесу);

4) завершальний (практичний або представницький) етап передбачає розробку практичних 
Наукові підходи до трактування поняття «науково-дослідницька компетентність»

Сукупність дослідницьких умінь, навичок та способів діяльності, що дає змогу залучити студента на позицію дослідника, сприяє розвитку його творчих здібностей, пізнавальних інтересів, активізації і підвищенню ефективності та якості навчально-пізнавальної діяльності.

Володіння методологією і методами інженерно-педагогічного дослідження, процесу планування, організації та здійснення пошуково-перетворювальної діяльності, об'єктом якої виступають психолого-педагогічна і галузева складові частини [1]

Засіб повноцінного автономного функціонування особистості в гетерогенному мультикультурному соціальному, профресійному та інфрормаційно-комунікаційному просторі [2] Інтегральна якість особистості, що виражається в готовності і здатності до самостійного пошуку вирішення нових проблем і творчого перетворення дійсності на основі сукупності особистісно усвідомлених знань, умінь, навичок, способів діяльності і ціннісних установок [4]

Автор

Якість особистості адекватно оцінювати результати своєї науково-дослідної діяльності, що здійснена на основі стійкої мотивації та сукупності відповідних знань, умінь і навичок [5]

Інтегративна властивість особистості, що характеризує готовність до вирішення дослідних (проблемних, освітніх, навчально-професійних, психолого-педагогічних) завдань шляхом застосування методів наукового пізнання, самостійно-пошукових методів у цілепокладанні, плануванні, програмуванні, прийнятті управлінських рішень, яка виражається в єдності ціннісно-мотиваційного, когнітивного, операційного й особистісного компонентів [6]

Комбінація системних полідисциплінарних інтегрованих знань, багатофункціональних пізнавальних умінь, що постійно розвиваються в навчальній, науково-дослідницькій проєктивній діяльності, а також високої мотивації та позитивних ставлень до наукового пошуку та пізнавальних цінностей (любов до істини, прагнення до творчості та вдосконалення) [7]

Характеристика, що передбачає володіння вміннями та способами дослідницької діяльності на рівні технології для пошуку знань для вирішення освітніх проблем, побудови освітнього процесу відповідно до цінностей, цілей сучасної освіти, місії освітнього закладу, бажаного результату [8]

Здатність учителя-фрілолога виокремлювати наукові проблеми в царині іноземної фрілології / іншомовної освіти, що потребують вирішення, проводити дослідження з вибраної проблематики з урахуванням особливостей галузі та впроваджувати отримані результати у процес іншомовної підготовки учнів [9]

рекомендацій і технологій (результатом є модель практичного перетворення вивченого явища, об'єкта, процесу) [12].

Зауважимо, що ознайомлення майбутніх фрахівців з інфрормаційної, бібліотечної та архівної справи із загальною методологією науково-дослідної роботи відбувається в межах дисципліни «Основи наукових досліджень».

Наукова діяльність, на переконання Д. Мацько, стає для студентів емоційно привабливою, якщо вони розуміють, що результати досліджень $є$ цікавими для наукової громадськості і використовуються в освітній практиці [9].

Ми переконані, що фрормування науководослідницької компетентності в майбутніх фрахівців з інформаційної, бібліотечної та архівної справи відбуватиметься ефективніше за умови розвитку в них мотивації до науково-дослідницької діяльності в процесі вивчення дисципліни «Основи наукових досліджень». Для цього важливо мотивувати студентів формулювати свої ідеї, знайомити з термінами, явищами, поняттями, які суперечать їхнім уявленням, спонукати до висування здогадів, аль- тернативних пояснень, давати їм змогу досліджувати свої припущення в комфрортній обстановці, не боячись зробити помилку, розширювати знання, уміння і навички, даючи змогу застосовувати їх на практиці, щоб студенти змогли оцінити їхнє практичне значення.

Для фрормування науково-дослідницької компетентності майбутніх фрахівців з інформаційної, бібліотечної та архівної справи важливе значення мають практичні завдання дослідницькопошукового характеру. Сутність таких завдань полягає в організації науково-пошукової діяльності студентів, спрямованої на розв'язання нових для них проблем. Цікавими, на нашу думку, можуть бути завдання, що описують поетапність наукового дослідження. Йдеться про спостереження і вивчення фрактів, виявлення незрозумілих, спірних явищ, які потребують дослідження (постановка проблеми), розробку та виконання плану дослідження, аналіз і систематизацію отриманих результатів, фрормулювання висновків та рекомендацій щодо практичного застосування. 
Ще одним цікавим методом фрормування науково-дослідницької компетентності майбутніх фрахівців з інфрормаційної, бібліотечної та архівної справи є проблемні ситуації. На думку С. Смірнова, вирішення проблемної ситуації $€$ завжди творчим і дослідницьким актом, результатом якого $€$ отримання конкретного знання, позитивне емоційне переживання успіху [11]. Щодо вибору проблемних завдань науковець наголошує, що, по-перше, вони мають викликати інтерес у студентів, по-друге, бути доступними, тобто спиратися на вже здобуті знання, по-третє, бути в «зоні найближчого розвитку», тобто бути одночасно і посильними, і не надмірно тривіальними, по-четверте, давати предметне знання відповідно до навчальних планів та програм, по-п'яте, розвивати профресійне мислення [11].

Висновки. Отже, відповідно до аналізу наукової літератури нами уточнено поняття «науково-дослідницька компетентність», а саме: це структурний елемент професійної компетентності фрахівця 3 інфрормаційної, бібліотечної та архівної справи, здатність, необхідна для здійснення пошуку інформації в різних джерелах для розв'язання професійних завдань, узагальнення, аналіз і синтез інформації в діяльності, пов'язаній з її пошуком, накопиченням, зберіганням та використанням. Науково-дослідницьку компетентність фрахівців 3 інформаційної, бібліотечної та архівної справи пропонуємо формувати за допомогою активного використання в освітньому процесі проблемних ситуацій і практичних завдань дослідницько-пошукового характеру, мотивуючи студентів до здійснення науково-дослідницької діяльності.

Перспективи подальших досліджень вбачаємо у визначенні механізмів фрормування науководослідницької компетентності майбутніх фрахівців з інформаційної, бібліотечної та архівної справи в процесі практичної підготовки.

\section{БІБЛІОГРАФІЧНИЙ СПИСОК:}

1. Архипова М. Дослідницька компетентність майбутніх інженерів-педагогів. Професійне становлення особистості: проблеми і перспективи : матеріали V міжнародної науково-практичної конференції, м. Хмельницький, 22-24 жовтня, 2009 р. Хмельницький, 2009. С. 144-148.
2. Бех І.Д. Компетентнісний підхід у сучасній освіті. Вища освіта України. Тематичний випуск «Педагогіка вищої школи»: методологія, теорії, технології». 2009. № 3. С. 21-24.

3. Бец І.О. Теоретичні основи формування науково-дослідницької компетентності майбутніх офріцерів-прикордонників. Збірник наукових праць Хмельницького інституту соціальних технологій Університету «Україна». 2011. № 4. C. 11-15. URL: http://nbuv.gov.ua/UJRN/Znpkhist_2011_4_4

4. Бібік Н.М., Ващенко Л.М., Локшина О.І., Овчарук О В., Паращенко Л.І. та ін. Компетентнісний підхід у сучасній освіті: світовий досвід та українські перспективи: Бібліотека з освітньої політики : Колективна монографрія / Під заг. ред. О.В. Овчарук. Київ : «К.І.С.» 2004. 112 с.

5. Вінник М.О. Науково-дослідницька компетентність майбутніх IT-срахівців. Педагогічний альманах. 2016. Вип. 29. С. 102-109. URL: http://nbuv.gov.ua/ UJRN/pedalm_2016_29_18

6. Євтух М.Б., Борисенко Л.Л. Науково-практичні підходи до проблеми формування науково-дослідницької компетентності майбутніх економістів. Духовність особистості: методологія, теорія і практика. 2012. № 5 (52). С. 88-104.

7. Зимняя И.А. Общая культура и социально-профессиональная компетентность человека. Высшее образование сегодня. 2005. № 11. С. 14-20.

8. Козырева О.А. Компетентность современного учителя: современная проблема определения понятия. Стандарты и мониторинг в образовании. 2004. № 2. C. 48-51.

9. Мацько Д.С. Формування науково-дослідницької компетентності - складової профресійної культури майбутніх учителів іноземної мови як провідна мета національної системи освіти України. Теоретико-методичні проблеми виховання дітей та учнівської молоді. 2016. Вип. 20 (1). С. 317-332. URL: $\quad$ http://nbuv.gov.ua/UJRN/Tmpvd_2016_20\% $281 \% 29 \_32$

10. Про затвердження стандарту вищої освіти за спеціальністю 029 «Інформаційна, бібліотечна та архівна справа» для першого (бакалаврського) рівня вищої освіти: Наказ МОН№1378від 12.12.2018р. URL: https://mon.gov.ua/storage/app/media/vishchaosvita/ zatverdzeni\%20standarty/12/21/029-informatsiynabibliotechna-ta-arkhivna-sprava-bakalavr.pdf

11. Смирнов С.Д. Педагогика и психология высшего образования: от деятельности к личности. Москва : Академия, 2003. 302 с.

12. Сурмин Ю.П. Теория систем и системный анализ : Учеб. пособие. Киев : МАУП, 2003. 368 с. 